Determinants of carbon emissions in a European emerging country: Evidence from ARDL cointegration and Granger causality analysis

Emilia Németh-Durkóa*

${ }^{a}$ Corvinus University of Budapest, Budapest, Hungary;

*durko.emilia@uni-corvinus.hu 


\title{
Determinants of carbon emissions in a European emerging country: Evidence from ARDL cointegration and Granger causality analysis
}

\author{
Hungary is one of the European Union's most dynamically developing countries \\ in Central-Eastern Europe with a high income and increasing level of \\ environmental degradation. The present study explores the dynamic relationship \\ between economic growth, electricity consumption, carbon emissions and \\ urbanization in Hungary for period 1974-2014 based on annual data. Using \\ autoregressive distributed lag model, we found long run relationship among the \\ variables in the presence of structural breaks and Toda-Yamamoto procedure \\ were applied to test causality. The findings indicate that electricity consumption \\ is positively linked with carbon emissions in the long run, which implies that the \\ energy efficiency should be improved. Urbanization have also positive effect on \\ carbon emissions meaning that the number of cities increases the emissions. \\ Causality results suggest that Hungary is growing at the cost of the environment \\ and the lack of the coordination of economic and environmental objectives to \\ fulfill emission reduction targets can reduce economic growth. The \\ reconsideration of the economic and energy policy is vital for ensuring \\ sustainable development and stricter environmental policy is suggested. These \\ results contribute not only to the expansion of the existing literature, but also \\ improves the methodological background by employing a new variable to capture \\ urbanization effect on carbon emissions.
}

Keywords: energy, economic growth, urbanization, Granger causality, TodaYamamoto approach, ARDL, conservation hypothesis, energy policy.

\section{Introduction}

With the acceleration of technological development and the improvement of economic mechanisms, the primary goal of policy makers since the Industrial Revolution has been to enhance the production. Although the energy-intensive production processes of the sectors of the national economy provide the basis of economic growth, but as a result our environment is at increased risk (Mazur et al. 2015). The role of energy is twofold in the relationship between economic growth and production. On one hand, energy is an 
essential source of the basis for economic activities. On the other hand, energy production has a primary role in pollutant emissions (IEA 2017).

As we can see in the action plans of 2030 Agenda for Sustainable Development, there is a great emphasis on the promoting of sustainable consumption and production to protect the planet. As for the future to maintain sustainable development, it is important to reveal past energy transitions in the direction of energy-economic growth nexus (Caglayan and Oskonbaeva 2011) especially in countries where economic growth is closely linked to energy production activities. In recent years, development efforts have focused not only on growth, but rather on sustainable growth. Today, it is irrelevant to focus only on economic growth and prosperity, as conscious strategic planning requires sustainability - also in environmental terms. Reconciling economic and environmental goals is necessary to create a long-term sustainable economic and natural environment.

Due to the importance of the topic, studies (Sharma 2011; Shahbaz et al. 2014; Shahbaz et al. 2014; Dogan and Seker 2016; Saidi and Hammami 2016; Pata 2018; Jiang and Ma 2019; Zhou et al. 2019; Munoz et al. 2020; Acheampong et al. 2020) analyzed the relationship among economic growth and carbon emissions for different countries. Empirical literature is wide-ranging but often with inconsistent results due to the applying of different data source, time set and usage of different econometric modelling. Some studies founded evidence that economic growth enhance carbon emissions in Europe (Stolyarova 2010; Ozturk and Acaravci 2010b; Gardiner and Hajek 2019) and some studies proves only the nexus among economic growth and electricity consumption (Ciarreta and Zarraga 2010; Stjepanovic 2018), while some studies denied significant relationship among variables (Menegaki 2011; Piaggio and Padilla (2012). 
However, we did not find any study examining the causal relationship between carbon emissions and economic growth in the case of Hungary.

The present study investigates the direction of causality between carbon emissions, economic growth and electricity consumption by taking into account urbanization as a potential determinant elements of the emission-growth nexus for Hungary. It worth to explore causal relationships in Hungary because with accelerating economic growth, the decline in carbon emissions has begun to stagnate despite efforts to protect the environment. This process could be effect economic growth because in emerging countries, the energy is the potential catalyst of economic growth and social development (Bergasse 2013; Wajahat et al. 2017; Ulutas and Caraca 2018; Liko 2019; Reilly 2015; Ulutas and Caraca 2018) where a reduction in energy production and pollutant emissions may cause decline in economic growth. Nowadays, Hungary is one of the fastest growing emerging economies in the European Union (Eurostat 2019) and at the same time Hungary has a high degree of air pollution (OECD 2018; WHO 2018; Eurostat 2019; IPSOS 2020).

Before 1990, Hungary was a socialist, plan-based economy. With the collapse of the Soviet Union and with the wave of regime change in 1989, a new period began in the economies of Central and Eastern European (CEE) countries as well as in Hungary. Hungary's transition differed from other CEE countries' process e.g. Bulgaria (Iorgulescu and Polimeni 2009, p. 342.) because the development of the open market system also brought a structural change in the energy sector as an important element of the economy (Gros and Steinherr 2004) and it will be the largest greenhouse gas emitting sector in Hungary (Hungarian Central Statistical Office 2015). However, the energy production has fallen sharply after the regime change, and the environmental indicators have shown noticeable improvement. After the 2008-2009 crisis, the services 
sector strengthened, which may also have contributed to the reduction in emissions.

However, the decline in emissions has slowed, stagnated, and begins to increase from 2013.

Urbanization has also increased in Hungary. In the 1970s, only 50 cities were registered in Hungary, representing $45 \%$ of the urban population. After the regime change, the number of cities jumped to 200 , although urban population (65\%) did not grow further to such an extent (Figure 1.). However, urbanization does not necessarily mean moving into a city or spreading an urban lifestyle. In Hungary, urbanization can be explained rather by the fact that the conditions for being declared a city have become more lax over time. For example, acquiring city status required only a population of $1-$ 2 thousand people compared to the ten-fold population requirement before the regime change. Higher standard of living is also debatable because new cities are designed to boost economic recovery in lower-income areas (Szepesi 2008). Consequently, we measure the effect of urbanization on carbon emissions with the number of cities instead of the proportion of city dwellers as in the literature employs (Poumayong and Kaneko 2010; Taale and Kyeremeh 2016; Gupta and Gregg 2018; Yang et al. 2019). As we confirmed in our previous study, the relationship between energy consumption and the level of urbanization (Durkó et al 2016a; Durkó et al 2016b; Durkó et al 2016c), we assume that the phenomenon of urbanization may also have affected Hungary's carbon emissions.

Figure 1. The number of cities and the proportion of urban population in Hungary between 1974 and 2014

The primary aim of this paper is to fill a research gap by presenting a relationship between economic growth, carbon emissions, electricity consumption, and urbanization in Hungary. To the best of our knowledge, this is the first study that 
examines Hungary exclusively and also the first one that examines the urbanization effect for Hungary. Second, the effect of urbanization is captured in the number of cities to find out real impact of the urban sprawl on carbon emissions. Third, in contrast to previous studies (Atici 2008; Mazur et al. 2015; Vavrek-Chovancova 2016; Lazar et al. 2019;) this study determines the causality relationships between energy-growth nexus and environmental protection. Exploring the causal relationships is especially important for political decision-makers to help them devise a proper energy strategy.

The paper is structured as follows. Section 2 provides a review of the relevant literature about economic growth and environmental degradation with special regard to the conditions in Hungary and Central and Eastern European emerging economies. Section 3 discusses the methodology. Section 4 presents the empirical results, after which Section 5 concludes by providing policy implications and further research objectives.

\section{Review of literature}

In the empirical literature, there are numerous studies currently investigating the challenges of energy management and its effect on economic growth. More than 15,000 studies have been published on this research topic since 1978 (Sanches-Pereira et al. 2016). However, classical energy-pollutant-growth relationship is less studied nowadays (Belke et al. 2011; Szép 2014; Caraiani et al. 2015) than in its earlier stages. In a globalized world, the focus is on a widespread model that eliminates extended carbon emissions by considering the economic and demographic impacts (Shahbaz et al. 2014; Ajmi et al. 2015; Dogan and Seker 2016; Saidi and Hammami 2016) and analyzing the interrelated effect of urbanization (Sharma 2011; Shahbaz et al. 2014; Saidi and Hammami 2016; Zhou et al. 2019; Munoz et al. 2020), financial development (Dogan and Seker 2016; Saidi and Hammami 2016; Pata 2018; Jiang and Ma 2019; 
Acheampong et al. 2020), and trade openness (Shahzad et al. 2017; Shahbaz et al. 2019; Zmami and Salha 2020) to pollutant emissions.

Empirical results have also confirmed the responsibility of urbanization in increasing carbon emissions and energy consumption. Urbanization contributes to enhance economic growth and energy use (Lariviére and Lafrance 1999; Poumayong and Kaneko 2010; Yang et al. 2019), increasing carbon emissions (Taale and Kyeremeh 2016; Gupta and Gregg 2018; Yang et al. 2019) by the trends of growing urban population and population density. Another group of empirical studies (Shammin et al. 2010; Poumayong and Kaneko 2010; Yang et al. 2019) justify the opposite with economies of scale, because cities show an improvement in per capita energy use and emissions compared to villages (Lenzen et al. 2004; Shammin et al. 2010; Ye at al. 2017). Thus, the urbanization sprawl in these emerging economies can also be identified as a key to enforce environmental protection.

Pablo-Romero and Sánchez-Braza (2017) observed that for the 28 Member States of the European Union, only four of them managed to decrease carbon emissions with increasing economic grow. All four countries are older founding countries of the European Union and produce higher GDP per capita than the other analyzed countries. Empirical evidence since the 1980s suggest that increase in economic growth results greater energy consumption because energy is the basis of economic growth, enhanced environmental pollution (Ciarreta and Zarraga, 2010). Carbon emissions are contributed to the increase in energy consumption (Ozturk - Acaravci, 2010) in Eastern-Europe (Stolyarova, 2010). However, economic growth can be a good tool for improving the environment, but only after reaching a higher level of income (Atici, 2008).

Overall, economic growth is significantly linked with increased emissions, with the exception of a few Central-Eastern European countries, where more intensive 
economic growth has been achieved without significant environmental degradation between 1996 and 2015 (Lazar et al. 2019). Only a few studies examine the emerging countries in Central and Eastern Europe, and we can find even less results which mentioned Hungary (Table 1). The energy-growth results in connection with Hungary is mentioned as Hungary a member of the European Union (Ozturk and Acaravci 2010b; Karmellos et al. 2016; Gazi et al. 2016; Lazar et al. 2019), as an emerging economy (Ozturk and Acaravci 2010; Ronald et al. 2014), or a member state of Visegrad Group (V4 countries) (Streimikiene and Kasperowicz 2016; Vavrek and Chovancova 2016).

\section{[Table 1 near here]}

Table 1. Some recent selected studies

Note: GDP: economic growth, $\mathrm{CO} 2$ : carbon emissions, POP: population, EC: electricity consumption, EP: energy prices, TO: trade openness, ENC: energy production, RES: renewable energy sources, GHG: greenhouse gases, UNEMP: unemployment, FDI: financial development. $<->$ means bidirectional causality, $->$ and $-<$ means unidirectional causality

Table 1 shows that there are three types results for Hungary, that is, the

bidirectional relationship between GDP and energy consumption in one case, no causal relationship between GDP and energy in the second case, and no long-run relationship between the variables in the third case. On the other hand, only conservation hypothesis was proven for Hungary (Narayan and Narayan 2010; Ronald et al. 2014; Caraiani et al. 2015). However, the role of emissions were not investigated.

As we have seen, many studies have investigated the energy-growth nexus, but only a few have examined Hungary and even less focused on emission and economic growth causal relationships. To the best of our knowledge, this paper is the first, which exclusively analyzes the causal relationship in an extended economic growth-energy nexus with urbanization employing ARDL cointegration framework in the Hungarian context. 


\section{Methodological framework}

\subsection{Data and empirical modeling}

The study covers the time period of 1974-2014 in case of Hungary. Annual data on carbon emissions and population have been collected from the World Bank (2018) and World Bank (2018b). Electricity consumption data are obtained from the Hungarian Energy and Public Utility Regulatory Authority (MEKH). Urbanization data was derived from the Hungarian Statistical Office (KSH). Similar, to Galli (1998), Medlock and Soligo (2001), and Agovino et al. (2018), data for economic growth (real GDP) is sourced from Penn World Table from Groningen Growth and Development Centre (GGDC).

All series data have been translated to per capita values and in logarithmic form. Using the general form, the empirical equation is the following:

$C O 2_{t}=f\left(E C_{t}, G D P_{t}, U R B_{t}\right)$

where $\mathrm{CO} 2_{\mathrm{t}}$ is the carbon emission per capita (metric kilotons), $\mathrm{EC}_{\mathrm{t}}$ is the electricity consumption per capita (kt of oil equivalent), GDPt is the real GDP per capita (2011; million US dollar) and $\mathrm{URB}_{\mathrm{t}}$ shows the spread of urbanization (expressed in terms of the number of the cities).

\subsection{The ARDL bounds testing of cointegration}

In current study, the Autoregressive Distributed Lag (ARDL) methodology was employed for checking cointegration among carbon emissions, electricity consumption, economic growth, and urbanization in Hungary using annual time series data for the period of 1974 to 2014. The ARDL method was developed by Pesaran et al. (2001). The ARDL bounds test has several econometrics advantages over other cointegration tests. 
It is applicable when variables have mixed stationarity properties (Pesaran et al. 2001) and suitable for small sample size data providing better estimates for small sample data (Haug 2002).

For the bounds test approach, we composed vector error correction model (VECM). The VECM has short run dynamics with long-term equilibrium, without losing any long-term information (Shahbaz et al. 2014). The empirical structure of the ARDL bounds testing to cointegration is expressed as the following (Begum et al. 2015; Rahman and Kashem 2017):

$\Delta \operatorname{lnCO2} 2_{t}=\alpha_{0}+\sum_{i=1}^{p} \beta_{i} \Delta \operatorname{lnCO} 2_{t-i}+\sum_{j=1}^{q} \gamma_{j} \Delta \ln E C_{t-j}+\sum_{k=1}^{q} \delta_{k} \Delta \ln G D P_{t-k}+$ $\sum_{l=1}^{q} \vartheta_{l} \Delta \ln U R B_{t-l}+\alpha_{1} \operatorname{lnCO} 2_{t-1}+\alpha_{2} \ln E C_{t-1}+\alpha_{3} \ln G D P_{t-1}+\alpha_{4} \ln U R B_{t-1}+\varepsilon_{t}$

where $\Delta$ is the first difference operator and $\varepsilon_{t}, \mu_{t}, \pi_{t}$ and $\omega_{t}$ are terms assumed to be normally distributed and white noise. The terms $\beta, \gamma, \delta, \vartheta$ in summation signs are shortrun coefficients representing the dynamics for error correction in the short run, while $\alpha$ is the long-run multiplier. The next half of the equation corresponds to the long-run relationship.

After founding evidence for cointegration between variables, the next step is estimating the long run coefficient of the ARDL model using the following equation (Begum et al. 2015; Rahman and Kashem 2017):

$\operatorname{lnCO} 2_{t}=\alpha_{0}+\sum_{i=1}^{p} \beta_{i} \ln C O 2_{t-i}+\sum_{j=0}^{q 1} \gamma_{j} \ln E C_{t-j}+\sum_{k=0}^{q 2} \delta_{k} \ln G D P_{t-k}+$ $\sum_{l=0}^{q 3} \alpha_{l} \ln U R B_{t-l}+\varepsilon_{t}$

Having obtained the value of the long-run coefficient, the cointegrating vector of the ARDL model is reparametrized to form an error correction mechanism (ECM). The reparametrized result provides short-run dynamics (i.e., traditional ARDL) and the longrun relationship of the variables of a single model. A negative and significant value of 
the error correction term (ECT) is expected to support long run relationship (Rahman and Mamun 2016; Shahbaz et al. 2013; Rahman and Kashem 2017).

\subsection{Causality analysis}

In the case of cointegration vector founding between the series, Granger causality is most likely to exist. However, the conventional Granger causality test based on ECM cannot eliminate bias and spurious results because most economic time series do not have the same stationarity properties, they have different integrated orders and might be mutually cointegrated or non-cointegrated. Toda and Yamamoto (1995) developed a test to reveal Granger causality regardless of the stationarity properies of the variables. The Toda-Yamamoto approach estimates causality between variables at levels under an augmented Vector Autoregression (VAR) framework. The VAR models are expressed as augmented Granger-causality (Faisal et al. 2016):

$\operatorname{lnCO} 2_{t}=\alpha_{0}+\sum_{i=1}^{k} b_{1 i} \operatorname{lnCO2} 2_{t-i}+\sum_{i=k+1}^{k+d m a x} b_{2 i} \operatorname{lnCO} 2_{t-i}+\sum_{i=1}^{k} c_{1 i} \ln E C_{t-i}+$

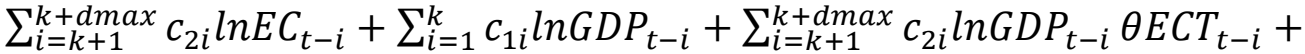
$\sum_{i=1}^{k} c_{1 i} \ln U R B_{t-i}+\sum_{i=k+1}^{k+d \max } c_{2 i} \ln U R B_{t-i}+\varepsilon_{1 t}$

where $\operatorname{lnCO} 2_{\mathrm{t}}$ is the dependent variable, $\mathrm{k}$ is the number of lags, and dmax is the number of augmented lags. The Toda-Yamamoto method is based on a Wald test in a VAR framework used regardless of the integrated order of the variables.

\subsection{Diagnostic and stability tests}

Diagnostic tests indicate the robustness of the estimated coefficients. Serial independence and normal distribution of error terms are both crucial assumptions in the ARDL Bounds testing methodology. This study employed the Breusch-Godfrey Serial Correlation LM test for testing serial independence, White test for testing heteroscedasticity, and the Jarque-Bera test for checking normality of the error terms in 
the model equations. The stability of the model can be deduced from the long-run results based on the cumulative sum of recursive residuals (CUSUM) and cumulative sum of recursive residuals of squares (CUSUMQ) in the graphical representation of the figures (Pesaran and Pesaran 1997; Brown et al. 1975).

\section{$4 \quad$ Empirical results and analysis}

\subsection{Unit root testing}

The prerequisite of the ARDL bounds testing is that time series should be integrated at level or after taking first difference. We applied not only traditional unit root tests such as the augmented Dickey-Fueller test (1979) but also the Zivot-Andrews test (ZivotAndrews 1992) with a single unknown break to ascertain all the variables for meeting the stationarity requirements of the ARDL bounds test. We can see in Table 2 that series have mixed integrated properties but none of the variables is integrated at second order. Unit root test results permitted us to employ the ARDL model technique to test cointegration.

\section{[Table 2 near here]}

Table 2. Unit root tests results

Note: $* * *$, and $* * *$ denote significance at $10 \%, 5 \%$, and $1 \%$ levels, respectively. The [] contains the appropriate lags of the variables which were selected using the Akaike Information Criteria (AIC).

Time break points occurred in the years following the Hungarian regime change in cases of all time series in 1993, 1994, 1991 and 1989, respectively. These dates can clearly be linked to the regime shift in Hungary where industrial production began to decline and a new open economy began (Romsics 2015). The real information about structural break dates may help the policy makers to make appropriate and sustainable plans for energy and economic policy. 


\subsection{ARDL bounds test and cointegration}

The ARDL bounds test revealed a long-run relationship between the variables. The long run relationship exists when the value of F-statistic exceeds the upper bound. Since we have a small sample, we use Narayan critical values to make a decision whether cointegration exist. The calculated F-statistic for the ARDL bounds test is 7.2591 for $\mathrm{k}=3$ ( $\mathrm{k}$ is the number of the independent variables) concluded that there is cointegration between carbon emissions, electricity consumption, economic growth and urbanization in Hungary. The null hypothesis of no cointegration can be rejected at the $1 \%$ level of significance in case of the $\mathrm{F}_{\mathrm{lnCO} 2 \mathrm{t}}, \mathrm{F}_{\mathrm{lnECt}}, \mathrm{F}_{\mathrm{lnGDP}}$, and $\mathrm{F}_{\text {lnURBt }}$ models. The calculated Fstatistics were $7.2591,7.0414,6.6750$, and 16.005 respectively, which are above the critical values not only from Narayan (2005) but also Pesaran (2001) as well as those from the statistical program. Results of critical values significantly suggest that all the models should be involve cointegration vectors (Table 3).

\section{[Table 3 near here]}

Table 3. Results of ARDL cointegration test and critical values from Pesaran et al. (2001) and Narayan (2005) for bounds testing

Note: $* * *$ denotes the significance at $1 \%$ level. Lag lengths were decided by evaluating Akaike Information Criterion. The diagnostics tests are the Breusch-Godfrey LM test for serial correlation and White test for heteroscedasticity. Lower and upper bonds are calculated with the statistical program.

The empirical models passed the three major diagnostic tests. The results of diagnostic tests indicated that the error terms is free from serial correlation, having normal distribution, and heteroscedasticity exists when the dependent variables are $\operatorname{lnCO} 2_{t}, \operatorname{lnEC} C_{t}, \operatorname{lnGDP}$ and $\ln \mathrm{URB}_{\mathrm{t}}$. The null hypothesis of $\mathrm{ARCH}$, non-normality, and heteroscedasticity problems could not be rejected, leading us to the conclusion that the parameter stability of the model is ensured. 


\subsection{Long and short-run analysis}

After identifying the existing of cointegration relationship, the next step is to reveal the long-run equilibrium relationship between the variables using the ARDL specification $(2,1,5,5)$. We found that a $1 \%$ raise in electricity consumption is linked with $2.507 \%$ increase in carbon emissions in the long run. If $1 \%$ increase occurs in urbanization, carbon emissions are increased by $2.138 \%$ in the analyzed period (Table 4.). Only economic growth decreases carbon emissions, holding electricity consumption and urbanization constant. However, the impact is not significant, which can be explained by two reasons. First, Hungary's economy became an open economy and started to grow only after 1989 (Gros and Steinherr 2004; Iorgulescu and Polimeni 2009), in the middle of the sample period. Second, the new economy model was mostly based on the service sector (IEA 2018) requiring less energy production than before as an industrydriven economy (KSH 2015).

\section{[Table 4 near here]}

Table 4. Long-run and short-run analysis result (error correction representation)

Note: $* * *, * * *$ denote significance at $10 \%, 5 \%$ and $1 \%$ levels, respectively. $\mathrm{ecm}=\operatorname{lnCO} 2-2.5068 * \operatorname{lnEC}+0.076377 * \ln$ GDP $-2.1384 * \ln U R B+0.13202 *$ TREND $+19.0568 *$ INT

Similar to our results, Richmond and Kaufmann (2006) employed the OLS method in levels concluded that a significant relationship does not exist between economic growth and carbon emissions series. Piaggio and Padilla (2012) and Ozturk and Acaravci (2010)b also found no evidence of a long-run relationship for Hungary between economic growth and carbon emissions. The present results are partly the same as the results of Gazi et al. (2016). The findings regarding the urbanization effect on carbon emissions are in a line with those of Poumayong and Kaneko (2010) and contrary to those of Sadorsky (2014). 
The coefficient of the lagged error correction term is negative and significant, validating the stable cointegrating relationship between the variables. The ECM measures the speed of adjustment of the endogenous variable in the case of a shock in the equilibrium. In this study, the ECM estimation suggested that short-run deviations in carbon emissions were corrected by $41.3 \%$ every year toward the long equilibrium (Table 4). Other words, in Hungarian conditions, carbon emissions return to its original equilibrium state in less than three years.

We can see the estimated effect of the electricity consumption on carbon emissions was positive, suggesting that an increase in electricity consumption results in increasing carbon emissions. Economic growth and carbon emissions were also found to be positively related meaning that an increase in economic growth enhances carbon emissions in short run. However, the direction of the effect of economic growth on carbon emissions was time varied. Therefore, it may be concluded that economic growth leads to environmental degradation only years later.

All other things being equal, all the lagged values of the coefficients in urbanization and carbon emissions were negatively linked at a $1 \%$ level of significance. Findings suggests that the spread of cities reduces carbon emissions in the short run. The more the number of cities, the less the damage to the environment. The effect of urbanization on carbon emission is time invariant.

\subsection{Granger causality test}

Engle and Granger (1987) suggest that if cointegration exists between the variables in the long run, then there must be either unidirectional or bidirectional Granger causality between variables. Finally, the causal relationship between carbon emissions and independent variables were tested using the Toda-Yamamoto Granger causality test. The result shows that carbon emissions were caused by all other variables in Hungary 
(Table 5).

[Table 5 near here]

Table 5. Granger causality/block exogeneity Wald test

Note: $* * *$ and $* * *$ denote significance at $10 \%, 5 \%$, and $1 \%$ levels, respectively.

The null hypothesis of no causality should be rejected when carbon emissions are the dependent variable at a $1 \%$ significance level. We found that unidirectional causality running from electricity consumption, economic growth, and urbanization to carbon emissions. All the selected series Granger cause carbon emissions in the long run, but the inverse does not hold true, since the causality is not bi-directional. The results of Ajmi et al. (2015) were partially confirmed by the present study, meaning that economic growth and electricity consumption determine the carbon emissions. Similar to the studies of Stolyarova (2010) and Ozturk and Acaravci (2010b), the causal effect of economic growth and electricity consumption, respectively, on carbon emissions was corroborated by the present study.

Feedback hypothesis was partially proved between economic growth and energy consumption similar to Ozturk and Acaravci (2010) for Hungary. Unidirectional Granger causality exists from economic growth to electricity consumption, implying that the neutrality hypothesis does not hold for these variables unlike in the case of Piaggio and Padilla (2012), Ozturk and Acaravci (2010)b and Menegaki (2011). We failed to detect a causal relationship for urbanization with any variables. However, urbanization Granger causes carbon emissions (Figure 2.). The Granger causality of urbanization has not been tested on Hungarian data thus far, and therefore the obtained results regarding urbanization cannot be compared with the results of previous literature. 
Figure 2. Causal Channels

Note: The line means $1 \%$ and the dotted line and the frame mean $10 \%$ level of significance.

\subsection{Diagnostic and stability test}

The results of diagnostic and stability tests indicate that the ARDL model is well fitted, as proved by the value of $R^{2}$ and the value of adjusted $R^{2}(0.841$ and 0.691 respectively). The value of the Durbin-Watson test statistics is 1.85 , which implies that spurious regression does not exist in the model. Diagnostic tests confirmed no problems with phenomena of either autocorrelation or heteroscedasticity and the model did not suffer from non-normality. The graphical representations of CUSUM and CUSUMSQ statistics are presented in Figure 3, respectively verifying the stability of the ARDL model.

Figure 3. Plot of the cumulative sum of recursive residuals and the Plot of the cumulative sum of squares of recursive residuals

\section{Conclusions and policy recommendations}

The study investigates the long-run and causal relationships between carbon emissions, electricity consumption, economic growth and urbanization in Hungary over the period of 1974-2014. The results of ARDL bounds testing method confirmed the dynamic relationship between the variables in the presence of structural breaks. The findings showed that electricity consumption and urbanization have a positive and significant effect on carbon emissions in the long run, while the impact of economic growth on carbon emission is negative and insignificant. We reveal that unidirectional causal relationship exist from electricity consumption, economic growth, and urbanization to carbon emissions, proving the validity of conservative hypothesis. Unidirectional Granger causality was found to run from economic growth to electricity consumption, unlike in the case of existing empirical evidence, the neutrality hypothesis does not 
hold.

Policy recommendations are based on the causality relationship found between carbon emissions, electricity consumption, economic growth, and urbanization simultaneously. Since electricity consumption is responsible for the rise of carbon emissions, energy efficiency programs and improvements have been developed for reaching environmental and social benefits as well as for the improvement of economic actors and society. More importantly, both economic growth and electricity consumption cause emissions, and economic growth causes electricity consumption. Thus, the Hungarian economy can only grow sustainably by mitigating the pollution per unit of electricity consumption. Hungary is now lagging behind the European Union nations in terms of energy intensity per unit of GDP and energy efficiency (Eurostat 2019). It proposes to remove barriers by implementing energy efficiency support programs (Czakó 2012). Moreover, the feedback hypothesis is valid for the energyeconomic growth nexus and electricity consumption is a good indicator of economic development. It is therefore not directly recommended to reduce electricity consumption, because economic growth may decline.

Considering the results reported above, the study suggests that in order to reduce carbon emissions in Hungary, measures need to be taken in all fields of energy and socio-economics. Regarding urbanization, the long-run and causality results emphasizes that urbanization cause and increase the pressure of carbon emissions on the environment. Based on this evidence, supporting rural life is proposed from an environmental point of view. Increasing rural employment opportunities and improving housing conditions can make the rural lifestyle more attractive to young couples, resulting in a good future direction. The 2019 government decree proposing support for the purchase of housing in villages (namely the village family housing benefit "csok") 
may also have environmental benefits. It provides a non-refundable grant for purchasing a family home for young families with children willing to settle with a maximum 5,000 inhabitants in the countryside (Kormány.hu 2020).

Towards this end, limitations need to be mentioned which can be covered by future research. As causal effect towards urbanization was not revealed, we suggest investigating the urbanization characteristic in a city-level framework. In order to better understand the relationship between environmental degradation and urbanization in Hungary, other important variables, such an urban density on a city level, should be considered to measure country-specific evidence with empirical analysis and thus present a reliable picture for policy and decision makers to help them revisit environmental and economic goals.

\section{Acknowledgement}

The author gratefully acknowledges the support of this research study by the grant no. 207643/2018/FEKUTSRTAT from the Higher Education Institutional Excellence Program in the framework of the 'Financial and Public Services' research project at Corvinus University of Budapest."

\section{Disclosure statement}

The author declares no conflict of interest.

\section{Funding}

"This work was supported by the Higher Education Institutional Excellence Program of the Ministry of Human Capacities in the framework of the 'Financial and Public Services' research project (20764-3/2018/FEKUTSRTAT) at Corvinus University of Budapest." 


\section{References}

Acheampong AO, Amponsah M, Boateng E. 2020. Does financial development mitigate carbon emissions? Evidence from heterogeneous financial economies. Energy Econ. 88:104768.

Agovino M, Bartoletto S, Garofalo A. 2018. Modelling the relationship between energy intensity and GDP for European countries: An historical perspective (18002000). Energy Econ. 82:114-134.

Ajmi AN. Hammoudeh, Nguyen DK, Sato JR. 2015. On the relationships between CO2emissions, energy consumption and income: The importance of time variation. Energy Econ. 49:629-638.

Atici C. 2008. Carbon emissions in Central and Eastern Europe: environmental Kuznets curve and implications for sustainable development. Sust Dev. 17(3):155-160.

Begum RA, Sohag K, Abdullah SMS, Jaafar M. 2015. CO2 emissions, energy consumption, economic and population growth in Malaysia. Renew Sust Energ Rev. 41:594-601.

Bergasse E. 2013. The Relationship between Energy and Socio-Economic Development in the Southern and Eastern Mediterranean. MEDPRO Technical Report No. 27/February 2013. [accessed 2019 July 22]. https://www.medproforesight.eu/system/files/MEDPRO\%20TR\%20No\%2027\%20WP4b\%20Bergas se_2.pdf

Brown R, Durbin LJ, Evans JM. 1975. Techniques for testing the constancy of regression relationships over time. J R Stat Soc. 37:149-192.

Caglayan A, Oskonbaeva Z. 2011. Analyzing of the validity of energy-growth hypothesis in 11 countries. J L Econ. 8:102-117.

Caraiani C, Lungu CI, Dascalu C. 2015. Energy consumption and GDP causality: A three-step analysis for emerging European countries. Renew Sust Energ Rev. 44:198-210.

Ciarreta A, Zarraga A. 2010. Economic growth-electricity consumption causality in 12 European countries: a dynamic panel data approach. Energy Policy. 38(7):37903796.

Czakó V. 2012. Evolution of Hungarian residential energy efficiency support programmes: road to and operation under the Green Investment Scheme. Ener Efficiency. 5:163-178. 
Dickey DA., Fuller WA. 1979. Distribution of the Estimators for Autoregressive Time Series with a Unit Root. J American Stat Assoc. 74(366): 427-431

Dogan E, Seker F. 2016. The influence of real output, renewable and non-renewable energy, trade and financial development on carbon emissions in the top renewable energy countries. Renew Sust Energ Rev. 60:1074-1085.

Durkó, E, Huzsvai L, Csipkés M. 2016a. Modelling the electrical energy use of city and provincial households in Hungary. Regional Review, 12: 5-19.

Durkó, E, Huzsvai L, Csipkés M. 2016b. A magyarországi községekben élő háztartások villamosenergia fogyasztásának modellezése. [Modeling of electricity consumption of households living in Hungarian villages] Hungarian. A Falu, 31: 27-35.

Durkó, E, Huzsvai L, Csipkés M. 2016c. Városi és vidéki háztartások villamosenergia fogyasztásának modellezése Magyarországon. [Modeling of electricity consumption of urban and rural households in Hungary]. Hungarian. Econom, 2: $28-41$.

Engle RF, Granger CJ. 1987. Cointegration and error-correction: representation, estimation and testing. Econometrica 55:251-278.

Eurostat 2019. Energy, transport and environment statistics. [accessed 2020 November 15]. https://ec.europa.eu/eurostat/documents/3217494/10165279/KS-DK-19001-EN-N.pdf/76651a29-b817-eed4-f9f2-92bf692e1ed9

Faisal F, Tursoy T, Resatoglu NG. 2016. Energy Consumption, Electricity, and GDP Causality; The Case of Russia, 1990-2011. Procedia Economics and Finance. 39:653-659.

Galli R. 1998. The relationship between energy intensity and income levels: forecasting long term energy demand in Asian emerging countries. Energy. 19(4):85-105.

Gardiner R, Hayek P. 2019. Interactions among energy consumption, CO2, and economic development in European Union countries. Sust Dev. 28(4):723-740.

Gazi AA, Uddin S, Sohag K. 2016. Biomass energy, technological progress and the environmental Kuznets curve: Evidence from selected European countries. Biom Bioener. 90:202-208.

GGDC. 2018. Groningen Growth and Development Centre. Data for Hungary GDP. [accessed 2018 July 1]. https://www.rug.nl/ggdc/productivity/pwt/

Gros D, Steinherr A. 2004. Economic transition in Central and Eastern Europe. Cambridge (UK). Cambridge University Press. 
Gupta R, Gregg M. 2018. Assessing energy use and overheating risk in net zero energy dwellings in UK. Energy Build. 158: 897-905.

Haug AA. 2002. Testing linear restrictions on cointegrating vectors: sizes and powers of Wald and Likelihood Ratio tests in finite samples. Econ Theory. 18(02):505524.

IEA. International Energy Agency. 2017. Hungary. 2017 review. [accessed 2019 December 10.] https://www.iea.org/publications/freepublications/publication/EnergyPoliciesofI EACountriesHungary2017Review.pdf

Iorgulescu RI, Polimeni JM. 2009. A multi-scale integrated analysis of the energy use in Romania, Bulgaria, Poland and Hungary. Energy. 34:341-347.

IPSOS. 2020. Earth Day 2020. [accessed 2020 Jan 8.] https://www.ipsos.com/sites/default/files/ct/news/documents/2020-04/earth-day2020-ipsos.pdf

Jiang C, Ma X. 2019. The impact of financial development on carbon emissions. Sustainability. 11:5241.

Karmellos M, Kopidou D, Diakoulaki D. 2016. A decomposition analysis of the driving factors of $\mathrm{CO} 2$ (Carbon dioxide) emissions from the power sector in the European Union countries. Energy, 94. 680-692.

KSH. Hungarian Central Statistical Office. 2015. A nemzetgazdasági ágak üvegházhatású gáz és légszennyező anyag kibocsátása. [Emissions of greenhouse gases and air pollutants by sectors of the national economy.] Hungarian. [accessed 2019 December 15]. http://www.ksh.hu/docs/hun/xftp/idoszaki/pdf/uveghazhatas.pdf

KSH. Hungarian Central Statistical Office. 2018. Bruttó hazai termék (GDP) (1960-). [The GDP from 1960s.] Hungarian. [accessed 2019 Dec 15]. http://www.ksh.hu/docs/hun/xstadat/xstadat hosszu/h qpt001.html Kormány.hu. 2020. Village family housing benefit 'csok' is very popular [accessed 2020 Aug 1]. https://www.kormany.hu/en/prime-minister-s-office/news/villagefamily-housing-benefit-csok-is-very-popular

Lariviere I, Lafrance G. 1999. Modelling the electricity consumption of cities: effect of urban density. Energy Econ. 21(1): 53-66.

Lazar D, Minea A, Purcel AA. 2019. Pollution and economic growth: Evidence from Central and Eastern European countries. Energy Econ. 81:1121-1131. 
Lenzen M, Dey C, Foran B. 2004. Energy requirements of Sydney households. Ecol Econ. 49(3):375-399.

Liddle B, Lung S. 2014. Might electricity consumption cause urbanization instead?

Evidence from heterogeneous panel long-run causality tests. Global Environ Change. 24:42-51.

Liko G. 2019. Impacts of Energy Sector on Economy, Social and Political Landscape, and Sustainable Development. [accessed 2020 July 2]. DOI:

10.13140/RG.2.2.12626.91847

Mazur A, Phutkaradze Z, Phutkaradze J. 2015. Economic Growth and Environmental Quality in the European Union Countries -Is there Evidence for the Environmental Kuznets Curve? I J Manage Econ. 45:108-126.

MEKH. 2009. Statistical data of the Hungarian Power system 2009. [accessed 2018 Dec $15]$.

http://www.mekh.hu/download/6/cd/00000/ver_2009_evi_statisztikai_adatai.pdf

Menegaki AN. 2011. Growth and renewable energy in Europe: a random effect model with evidence for neutrality hypothesis. Energy Econ. 33(2):257-63.

Medlock KB, Soligo R. 2001. Development and end-use energy demand. Energy. 22 (2):77-105.

Munoz P, Zwick P, Mirzabaev A. 2020. The impact of urbanization on Austria's carbon footprint. J Clean Prod. 263:121-326.

Narayan PK. 2005. The saving and investment nexus for China: evidence from cointegration tests. Appl Econ. 37:1979-1990.

Narayan P, Narayan S. 2010. Carbon dioxide emissions and economic growth: panel data evidence from developing countries. Energy Policy. 38:661-666.

OECD. 2018. Organisation for Economic Co-operation and Development. OECD Environmental Performance Reviews: Hungary 2018. Paris. OECD Publishing.

Ozturk Y, Acaravci A. 2010. The causal relationship between electricity consumption and GDP in Albania, Bulgaria, Hungary and Romania: evidence from ARDL bound testing approach. Appl Ener. 87:1938-43.

Ozturk Y, Acaravci A. 2010b. On the relationship between energy consumption, CO2 emissions and economic growth in Europe. Energy. 35(12):5412-5420.

Pablo-Romero MP, Sánchez-Braza A. 2017. Residential energy environmental Kuznets curve in the EU-28. Energy. 125:44-54. 
Piaggio M, Padilla E. 2012. CO2 emissions and economic activity: Heterogeneity across countries and non-stationary series. Energy Policy. 46:370-381.

Pesaran MH, Shin Y, Smith R. 2001. Bounds testing approaches to the analysis of level relationships. J. Appl. Econ. 16:289-326.

Pesaran HM, Pesaran B. 1997. Microfit 4.0 (Oxford University Press).

Poumanyvong P, Kaneko S. 2010. Does urbanization lead to less energy use and lower CO2 emissions? A cross-country analysis, Ecol Econ. 70(2):434-444.

Rahman MM, Kashem MA. 2017. Carbon emissions, energy consumption and industrial growth in Bangladesh: Empirical evidence from ARDL cointegration and Granger causality analysis. Energy Policy 110:600-608.

Reilly J. 2015. Energy and Development in Emerging Countries. Revue d'économie du développement.23:19-38.

Richmond AK, Kaufmann RK. 2006. Is there a turning point in the relationship between income and energy use and/or carbon emissions? Ecol Econ. 56:176-189.

Romsics I. 2015. Regime Change in Hungary. [accessed 2018 Dec 20]. http://www.enrs.eu/sk/articles/1562-regime-change-in-hungary

Ronald RK, Stauvermann PJ, Patel A, Kumar RD. 2014. Exploring the effects of energy consumption on output per worker: A study of Albania, Bulgaria, Hungary and Romania. Energy Policy. 69:575-585.

Saidi K, Hammami S. 2015. The impact of CO2 emissions and economic growth on energy consumption in 58 countries. Energy Reports. 1:62-70

Sadorsky P. 2009. Renewable energy consumption and income in emerging economies. Energy Policy. 37(10):4021-4028.

Sadorsky P. 2014. The effect of urbanization on CO2 emissions in emerging economies. Ener Econ. 41:147-153.

Sanches-Pereira A, Tudeschini LG, Coelho ST. 2016. Evolution of the Brazilian residential carbon footprint based on direct energy consumption. Renew Sust Energ Rev. 54:184-201.

Shahbaz M, Solarin SA, Mahmood H, Arouri M. 2013. Does financial development reduce $\mathrm{CO} 2$ emissions in Malaysian economy? A time series analysis. Econ Model. (35):145-152.

Shahbaz M. Mutascu M, Azim P. 2014. Environmental Kuznets curve in Romania and the role of energy consumption. Renew Sust Energ Rev. 18:165-173. 
Shahbaz M, Gozgor G, Adom P K, Hammoudeh S. 2019. The technical decomposition of carbon emissions and the concerns about FDI and trade openness effects in the United States. Int Econ. 159:56-73.

Shammin MR, Herendeen RA, Hanson MJ, Wilson EJ. 2010. A multivariate analysis of the energy intensity of sprawl versus compact living in the US for 2003. Ecol Econ. 69(12): 2363-2373.

Sharma SS. 2011. Determinants of carbon dioxide emissions: Empirical evidence from

Stolyarova E. 2013. Carbon Dioxide Emissions, economic growth and energy mix: empirical evidence from 93 countries. Eco Mod. 5433.

Streimikiene D, Kasperowicz R. 2016. Review of economic growth and energy consumption: A panel cointegration analysis for EU countries. Renew Sust Ener Rev. 59:1545-1549.

Szép T. 2014. The Granger causality analysis of energy consumption and economic growth. J Mark Manag Innov. 8:244-258.

Szepesi G. 2008. The city proclamations in Hungary after the System change. A rendszerváltozás utána várossá avatások Magyarországon. [After the change of regime, inaugurations became cities in Hungary.] Hungarian. Tér és társadalom. 22(2):55-70.

Taale F, Kyeremeh C. 2019. Drivers of households' electricity expenditure in Ghana. Energy Build. 205:109546.

Toda HY, Yamamoto T. 1995. Statistical inference in vector autoregressions with possibly integrated processes. Econometrics. 66(1-2):225-250.

Ulutas A, Karaca C. 2018. Selection of renewable energy sources for sustainable development and an economic model proposal for countries. Emerging Economic Models for Global Sustainability and Social Development. Global. Hershey, PA, USA.

Vavrek R, Chovancova J. 2016. Decoupling of Greenhouse Gas Emissions from Economic Growth in V4 Countries. Proc Econ Fin. 39:526-533.

Wajahat AW, Abdullah A, Azam M. 2017. Re-visiting the environmental Kuznets curve hypothesis for Malaysia: Fresh evidence from ARDL bounds testing approach. Renew Sust Ener Rev. 77:990-1000.

Wang Y, Hayashi Y, Chen J, Li, Q. 2014. Changing Urban Form and Transport CO2 Emissions: An Empirical Analysis of Beijing, China. Sustainability. 6:45584579. 
WHO. 2018. World Health Organization in Hungary. [accessed 2019 Aug 2].

https://www.euro.who.int/en/countries/hungary/publications/world-healthorganization-in-hungary-2018

World Bank. 2018. CO2 emissions in kt in Hungary. Carbon Dioxide Information Analysis Center, Environmental Sciences Division, Oak Ridge National Laboratory, Tennessee, United States. [accessed 2019 Aug 2]. https://data.worldbank.org/indicator/EN.ATM.CO2E.KT?locations=HU

World Bank. 2018b. Population in Hungary. [accessed 2019 Aug 2]. https://data.worldbank.org/indicator/SP.POP.TOTL?locations=HU

Yang Y, Liu J, Lin Y, Li Q. 2019. The impact of urbanization on China's residential energy consumption. Struc Chan Econ Dyn. 49:170-182.

Ye H, Qun Ren, Xinyue Hu, Tao Lin, Lilai Xinhu Li, and Bing Pan. 2017”. Low-carbon behavior approaches for reducing direct carbon emissions: Household energy use in a coastal city.” Journal of Cleaner Production, 141, pp. 128-136.

Zivot E, Andrews D. 1992. Further evidence of great crash, the oil price shock and unit root hypothesis. J. Bus. Econ. Stat. 10:251-270.

Zhou C, Wang S, Wang J. 2019. Examining the influences of urbanization on carbon dioxide emissions in the Yangtze River Delta, China: Kuznets curve relationship. Scien Tot Env. 20:472-482.

Zmami M, Ben-Salha O. 2020. An empirical analysis of the determinants of CO2 emissions in GCC countries. I J Sustainable Dev World Ecol. 27(5):469-480. 


\section{List of Tables}

Table 2. Some recent selected studies

Table 2. Unit root tests results

Table 3. Results of ARDL cointegration test and critical values from Pesaran et al. (2001) and Narayan (2005) for bounds testing

Table 4. Long-run and short-run analysis result (error correction representation)

Table 5. Granger causality/block exogeneity Wald test 


\section{Tables}

Table 3. Some recent selected European studies and the Hungarian results

\begin{tabular}{|c|c|c|c|c|c|c|}
\hline No & Study authors & Country & $\begin{array}{l}\text { Time } \\
\text { period }\end{array}$ & Methodology & Variables & Causality \\
\hline \multicolumn{7}{|c|}{ Evidences from groups of European countries } \\
\hline 1 & $\begin{array}{l}\text { Stolyarova } \\
(2010)\end{array}$ & $\begin{array}{l}\text { Eastern European } \\
\text { countries }\end{array}$ & $\begin{array}{l}1960- \\
2008\end{array}$ & $\begin{array}{l}\text { WITHIN, } \\
\text { SYS GMM }\end{array}$ & $\begin{array}{l}\text { GDP, CO2, } \\
\text { POP, EC, } \\
\text { Region }\end{array}$ & GDP->CO2 \\
\hline 2 & $\begin{array}{l}\text { Ciarreta and } \\
\text { Zarraga (2010) }\end{array}$ & $\begin{array}{l}12 \text { European } \\
\text { countries }\end{array}$ & $\begin{array}{l}1970- \\
2007\end{array}$ & $\begin{array}{l}\text { GMM, } \\
\text { VECM }\end{array}$ & $\begin{array}{l}\text { GDP, EC, } \\
\text { Energy prices }\end{array}$ & $\begin{array}{l}\text { EC-> GDP } \\
\text { EP<-> GDP } \\
\text { EP<->EC }\end{array}$ \\
\hline 3 & $\begin{array}{l}\text { Atici } \\
(2008)\end{array}$ & $\begin{array}{l}\text { Central-Eastern } \\
\text { Europe countries }\end{array}$ & $\begin{array}{l}1980- \\
2002\end{array}$ & RE, FE & $\begin{array}{l}\text { GDP, CO2, EC, } \\
\text { TO }\end{array}$ & - \\
\hline 4 & $\begin{array}{l}\text { Ozturk-Acaravci } \\
(2010) \mathrm{b}\end{array}$ & 19 EU countries & $\begin{array}{l}1980- \\
2006\end{array}$ & $\begin{array}{l}\text { ARDL, } \\
\text { VECM }\end{array}$ & GDP, EC, ENC & $\begin{array}{l}\text { GDP->ENC } \\
\text { CO2->ENC }\end{array}$ \\
\hline 5 & $\begin{array}{l}\text { Gardiner-Hajek } \\
\text { (2019) }\end{array}$ & EU-23 & $\begin{array}{l}1990- \\
2015\end{array}$ & $\begin{array}{l}\text { Granger } \\
\text { causality }\end{array}$ & $\begin{array}{l}\text { GDP, EC, CO2, } \\
\text { FDI, EMP }\end{array}$ & $\begin{array}{l}\mathrm{GDP}<->\mathrm{CO} 2 \\
\mathrm{GDP}<->\mathrm{EC} \\
\mathrm{EC}<->\mathrm{CO} 2\end{array}$ \\
\hline 6 & $\begin{array}{l}\text { Mazur et al. } \\
(2015)\end{array}$ & EU-28 & $\begin{array}{l}1992- \\
2010\end{array}$ & $\begin{array}{l}\text { FE-RE OLS } \\
\text { panel data }\end{array}$ & GDP, CO2 & - \\
\hline 7 & $\begin{array}{l}\text { Sadorsky } \\
(2009)\end{array}$ & $\begin{array}{l}18 \text { emerging } \\
\text { countries }\end{array}$ & $\begin{array}{l}1994- \\
2003\end{array}$ & $\begin{array}{l}\text { panel } \\
\text { cointegration }\end{array}$ & GDP, RES & GDP-> RES \\
\hline 8 & $\begin{array}{l}\text { Stjepanovic } \\
(2018)\end{array}$ & $\begin{array}{l}30 \text { European } \\
\text { countries }\end{array}$ & $\begin{array}{l}1994- \\
2016\end{array}$ & $\begin{array}{l}\text { panel } \\
\text { regression }\end{array}$ & GDP, EC & EC-> GDP \\
\hline 9 & $\begin{array}{l}\text { Lazar et al. } \\
\text { (2019) }\end{array}$ & EU-28 & $\begin{array}{l}1995- \\
2015\end{array}$ & FMOLS & GDP, CO2 & - \\
\hline 10 & $\begin{array}{l}\text { Menegaki } \\
(2011)\end{array}$ & $\begin{array}{l}27 \text { European } \\
\text { countries }\end{array}$ & $\begin{array}{l}1997- \\
2007\end{array}$ & $\begin{array}{l}\text { Granger } \\
\text { causality }\end{array}$ & $\begin{array}{l}\text { GDP, RES, } \\
\text { UNEMP, GHG }\end{array}$ & no causality \\
\hline \multicolumn{7}{|c|}{ Hungary } \\
\hline 1 & $\begin{array}{l}\text { Piaggio-Padilla } \\
(2012)\end{array}$ & 31 countries & $\begin{array}{l}1950- \\
2006\end{array}$ & $\begin{array}{l}\text { NLLS, } \\
\text { cointegration }\end{array}$ & $\mathrm{CO}_{2}, \mathrm{GDP}$ & $\begin{array}{l}\text { no long run } \\
\text { relationship }\end{array}$ \\
\hline 2 & $\begin{array}{l}\text { Narayan-Narayan } \\
(2010)\end{array}$ & 30 OECD countries & $\begin{array}{l}1960- \\
2002\end{array}$ & & GDP, EN & GDP->ENC \\
\hline 3 & $\begin{array}{l}\text { Ozturk-Acaravci } \\
(2010) b\end{array}$ & $19 \mathrm{EU}$ countries & $\begin{array}{l}1965- \\
2005\end{array}$ & $\begin{array}{l}\text { ARDL, } \\
\text { Granger } \\
\text { causality }\end{array}$ & $\mathrm{CO}_{2}, \mathrm{EN}, \mathrm{GDP}$ & no causality \\
\hline 4 & $\begin{array}{l}\text { Ozturk-Acaravci } \\
(2010)\end{array}$ & $\begin{array}{l}\text { Hungary, Albania, } \\
\text { Bulgaria, Romania }\end{array}$ & $\begin{array}{l}1980- \\
2006\end{array}$ & $\begin{array}{l}\text { ARDL, VEC, } \\
\text { Granger- caus. }\end{array}$ & GDP, EN, ENC & $\mathrm{GDP}<>\mathrm{ENC}$ \\
\hline 5 & $\begin{array}{l}\text { Caraiani et al. } \\
(2015)\end{array}$ & $\begin{array}{l}\text { Hungary, Bulgaria, } \\
\text { Romania, Poland, } \\
\text { Turkey }\end{array}$ & $\begin{array}{l}1980- \\
2013\end{array}$ & Granger caus. & GDP, EN & GDP->ENC \\
\hline 6 & Gazi et al. (2016) & $\begin{array}{l}24 \text { European } \\
\text { countries }\end{array}$ & $\begin{array}{l}1980- \\
2010\end{array}$ & ARDL, GMM & $\begin{array}{l}\text { CO2, GDP, } \\
\text { Technology, } \\
\text { Biomass }\end{array}$ & Biom.->CO 2 \\
\hline 7 & Szép (2014) & V4 countries & $\begin{array}{l}1990- \\
2009\end{array}$ & panel OLS & GDP, EN & EN->GDP \\
\hline 8 & $\begin{array}{l}\text { Vavrek- } \\
\text { Chovancova } \\
(2016)\end{array}$ & V4 countries & $\begin{array}{l}1991- \\
2012\end{array}$ & decoupling & $\mathrm{CO}_{2}, \mathrm{GDP}$ & - \\
\hline 9 & Ronald et al (2014) & $\begin{array}{l}\text { Hungary, Albania, } \\
\text { Bulgaria, Romania }\end{array}$ & $\begin{array}{l}1994- \\
2009\end{array}$ & $\begin{array}{l}\text { ARDL } \\
\text { TY non-caus. }\end{array}$ & $\begin{array}{l}\text { GDP, capital, } \\
\text { EC }\end{array}$ & GDP-> EC \\
\hline 10 & $\begin{array}{l}\text { Streimikiene- } \\
\text { Kasperowicz } \\
(2016)\end{array}$ & $\begin{array}{l}\text { V4 and } 14 \text { old EU } \\
\text { countries }\end{array}$ & $\begin{array}{l}1995- \\
2012\end{array}$ & $\begin{array}{l}\text { FMOLS, } \\
\text { DOLS }\end{array}$ & $\begin{array}{l}\text { GDP, EC, } \\
\text { Capital }\end{array}$ & 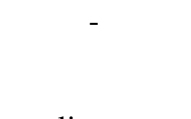 \\
\hline 11 & $\begin{array}{l}\text { Lazar et al. } \\
\text { (2019) }\end{array}$ & EU-28 & $\begin{array}{l}1995- \\
2015\end{array}$ & FMOLS & GDP, CO2 & $\begin{array}{l}\text { linear } \\
\text { relationship }\end{array}$ \\
\hline 12 & $\begin{array}{l}\text { Zachariadis- } \\
\text { Kouvaritakis } \\
\text { (2003) }\end{array}$ & $\begin{array}{l}\text { Central and Eastern } \\
\text { countries }\end{array}$ & $\begin{array}{l}2000- \\
2030\end{array}$ & forecast & GDP, transport & - \\
\hline 13 & $\begin{array}{l}\text { Karmellos et al. } \\
\text { (2016) }\end{array}$ & EU-28 & $\begin{array}{l}2000- \\
2012\end{array}$ & $\begin{array}{l}\text { decomposition } \\
\text { analysis, } \\
\text { LMDI }\end{array}$ & $\begin{array}{l}\text { GDP, EC, EI, } \\
\text { fuel mix, activity }\end{array}$ & - \\
\hline
\end{tabular}


Table 2. Unit root tests results

\begin{tabular}{|c|c|c|c|c|c|c|}
\hline \multicolumn{3}{|c|}{ Augmented Dickey-Fueller test } & \multicolumn{4}{|c|}{ Zivot-Andrews test } \\
\hline \multirow[b]{2}{*}{ Variables } & \multirow[b]{2}{*}{ Level } & \multirow[b]{2}{*}{ First diff. } & \multicolumn{2}{|c|}{ Level } & \multicolumn{2}{|c|}{ First diff. } \\
\hline & & & T-stat. & $\begin{array}{l}\text { Time } \\
\text { break }\end{array}$ & T-stat. & $\begin{array}{l}\text { Time } \\
\text { break }\end{array}$ \\
\hline $\operatorname{lnCO2}{ }_{t}$ & $-2.642[3]$ & $-6.405 * * *[0]$ & -3.419 & 2003 & $-5.234 * *[1]$ & 1993 \\
\hline $\ln E C_{t}$ & $-2.919[2]$ & $-2.667 * \quad[1]$ & -4.429 & 1990 & $-5.227 * *[0]$ & 1994 \\
\hline $\operatorname{lnGDP} P_{t}$ & $-4.07 \quad[2]$ & $-3.203 * *[1]$ & $-4.815 * \quad[1]$ & 1991 & $-5.726 * * *[0]$ & 1981 \\
\hline $\ln \mathbf{U R B}_{t}$ & $-0.992[2]$ & $-5.85 * * *[1]$ & $-8.324 * * *[0]$ & 1989 & $-9.435 * * *[0]$ & 1991 \\
\hline
\end{tabular}


Table 3. Results of ARDL cointegration test and critical values from Pesaran et al. (2001) and Narayan (2005) for bounds testing

\begin{tabular}{|c|c|c|c|c|c|}
\hline \multicolumn{3}{|c|}{ ARDL estimates } & \multicolumn{3}{|c|}{ diagnostic test } \\
\hline $\begin{array}{l}\text { Dependent } \\
\text { variable }\end{array}$ & optimal lag & F-stat. & serial corr. & normality & heteroskeda. \\
\hline $\operatorname{lnCO} 2_{t}$ & $2,1,5,5$ & $7.2591 * * *$ & $\begin{array}{c}0.4863 \\
{[0.486]}\end{array}$ & $\begin{array}{l}0.6454 \\
{[0.724]}\end{array}$ & $\begin{array}{l}0.0320 \\
{[0.858]}\end{array}$ \\
\hline $\operatorname{lnEC}_{t}$ & $3,3,5,5$ & $7.0414 * * *$ & $\begin{array}{l}0.6688 \\
{[0.413]}\end{array}$ & $\begin{array}{l}0.6688 \\
{[0.413]}\end{array}$ & $\begin{array}{l}0.0266 \\
{[0.870]}\end{array}$ \\
\hline $\operatorname{lnGDP}_{t}$ & $4,0,2,3$ & $6.6750 * * *$ & $\begin{array}{l}2.2956 \\
{[0.130]}\end{array}$ & $\begin{array}{c}0.94443 \\
{[0.624]}\end{array}$ & $\begin{array}{l}0.0129 \\
{[0.909]}\end{array}$ \\
\hline $\ln \mathrm{URB}_{\mathrm{t}}$ & $5,2,2,5$ & $16.0050 * * *$ & $\begin{array}{l}3.5859 \\
{[0.158]}\end{array}$ & $\begin{array}{l}1.5053 \\
{[0.471]}\end{array}$ & $\begin{array}{l}0.0129 \\
{[0.909]}\end{array}$ \\
\hline \multirow[b]{2}{*}{ Critical values } & \multicolumn{2}{|c|}{ Pesaran* } & \multicolumn{3}{|c|}{ Narayan* } \\
\hline & $\begin{array}{l}\text { Lower bound } \mathrm{I}(0) \\
\mathrm{I}(1)\end{array}$ & Uppe & $\begin{array}{l}\text { Low } \\
\text { I(1) }\end{array}$ & bound $\mathrm{I}(0)$ & Upper bond \\
\hline $1 \%$ & 4.29 & 5.6 & & 5.258 & 6.526 \\
\hline $5 \%$ & 3.23 & 4.3 & & 3.850 & 4.782 \\
\hline $10 \%$ & 2.72 & 3.7 & & 3.260 & 4.094 \\
\hline
\end{tabular}


Table 4. Long-run and short-run analysis result (error correction representation)

\begin{tabular}{|c|c|c|c|}
\hline \multicolumn{4}{|c|}{ Dependent variable: $\operatorname{lnCO} 2_{t}$} \\
\hline \multicolumn{4}{|c|}{ Long-run result } \\
\hline Variable & Coefficient & T-statistics & Probability \\
\hline $\operatorname{lnEC_{t}}$ & $2.507 * * *$ & 3.698 & 0.002 \\
\hline $\operatorname{lnGDP}_{t}$ & -0.076 & -0.123 & 0.903 \\
\hline $\operatorname{lnURB}{ }_{t}$ & $2.138 * *$ & 2.523 & 0.021 \\
\hline $\mathrm{C}$ & $-19.057 * *$ & -2.306 & 0.033 \\
\hline \multicolumn{4}{|c|}{$\begin{array}{l}\text { Short-run result } \\
\end{array}$} \\
\hline d. $\operatorname{lnCO} 21$ & $-0.6464 * * *$ & -3.940 & 0.001 \\
\hline d.lnEC & $1.668 * * *$ & 5.474 & 0.000 \\
\hline d.lnGDP & 0.051 & 0.246 & 0.808 \\
\hline d.lnGDP1 & 0.026 & 0.131 & 0.897 \\
\hline d.lnGDP2 & -0.172 & -1.065 & 0.299 \\
\hline d.lnGDP3 & $0.403 * * *$ & 2.919 & 0.008 \\
\hline d.lnGDP4 & 0.185 & 1.206 & 0.241 \\
\hline d.lnURB & $-0.324 * *$ & -2.321 & 0.030 \\
\hline d.lnURB1 & $-1.178 * * *$ & -3.605 & 0.001 \\
\hline d.lnURB2 & $-0.981 * * *$ & -3.131 & 0.005 \\
\hline d.lnURB3 & $-0.865 * * *$ & -3.633 & 0.002 \\
\hline d.lnURB4 & $-0.478 * *$ & -2.577 & 0.018 \\
\hline ecm(-1) & $-0.413 * *$ & -2.280 & 0.033 \\
\hline $\mathrm{R}^{2}$ & 0.841 & & \\
\hline Adj. $\mathrm{R}^{2}$ & 0.691 & & \\
\hline F-statistic & 6.810 & & \\
\hline DW test & 1.824 & & \\
\hline
\end{tabular}


Table 5. Granger causality/block exogeneity Wald test

\begin{tabular}{|c|c|c|c|c|}
\hline \multicolumn{4}{|c|}{ Dependent variable: $\operatorname{lnCO2}{ }_{t}$} & \multirow[t]{2}{*}{ Decision } \\
\hline Excluded & Chi-sq & $\overline{d f}$ & Prob. & \\
\hline $\ln \mathrm{EC}$ & 18.30241 & 5 & $0.0026 * * *$ & Reject $\mathrm{H}_{0}$ \\
\hline $\operatorname{lnGDP}$ & 29.88723 & 5 & $0.0000 * * *$ & Reject $\mathrm{H}_{0}$ \\
\hline $\ln U R B$ & 16.13513 & 5 & $0.0065 * * *$ & Reject $\mathrm{H}_{0}$ \\
\hline All & 36.68907 & 15 & $0.0014 * * *$ & Reject $\mathrm{H}_{0}$ \\
\hline \multicolumn{5}{|c|}{ Dependent variable: $\ln E C_{t}$} \\
\hline Excluded & Chi-sq & $\overline{d f}$ & Prob. & \\
\hline $\operatorname{lnCO} 2$ & 1.400771 & 5 & 0.9242 & Do not reject $\mathrm{H}_{0}$ \\
\hline $\operatorname{lnGDP}$ & 9.014018 & 5 & $0.1085^{*}$ & Reject $\mathrm{H}_{0}$ \\
\hline $\operatorname{lnURB}$ & 4.686348 & 5 & 0.4553 & Do not reject $\mathrm{H}_{0}$ \\
\hline All & 17.92080 & 15 & 0.2669 & Do not reject $\mathrm{H}_{0}$ \\
\hline \multicolumn{5}{|c|}{ Dependent variable: $\operatorname{lnGDP} P_{t}$} \\
\hline Excluded & Chi-sq & $\overline{d f}$ & Prob. & \\
\hline $\operatorname{lnCO} 2$ & 8.010204 & 5 & 0.1557 & Do not reject $\mathrm{H}_{0}$ \\
\hline $\operatorname{lnEC}$ & 4.470790 & 5 & 0.4838 & Do not reject $\mathrm{H}_{0}$ \\
\hline $\ln U R B$ & 8.481431 & 5 & 0.1316 & Do not reject $\mathrm{H}_{0}$ \\
\hline All & 22.87863 & 15 & $0.0868 *$ & Reject $\mathrm{H}_{0}$ \\
\hline \multicolumn{5}{|c|}{ Dependent variable: $\ln U R B_{t}$} \\
\hline Excluded & Chi-sq & $\overline{\mathrm{df}}$ & Prob. & \\
\hline $\operatorname{lnCO} 2$ & 2.035025 & 5 & 0.8443 & Do not reject $\mathrm{H}_{0}$ \\
\hline $\operatorname{lnECP}$ & 4.699540 & 5 & 0.4536 & Do not reject $\mathrm{H}_{0}$ \\
\hline $\ln G D P$ & 6.930296 & 5 & 0.2259 & Do not reject $\mathrm{H}_{0}$ \\
\hline All & 20.09699 & 15 & 0.1682 & Do not reject $\mathrm{H}_{0}$ \\
\hline
\end{tabular}




\section{List of Figures}

Figure 1. The number of cities and the proportion of urban population in Hungary between 1974 and 2014

Figure 2. Causal Channels

Figure 3. Plot of the cumulative sum of recursive residuals and the plot of the cumulative sum of squares of recursive residuals 